\title{
INDUCTION OF SYSTEMIC ACQUIRED RESISTANCE OF WHEAT SEEDLINGS AGAINST LEAF RUST DISEASE.
}

Thabet, Marian S. ${ }^{1}$; E.A.M. Gado'; M. A. A. Najeeb ${ }^{2}$ and S. H. El -Deeb ${ }^{1}$

1. Department of Plant Pathology, Faculty of Agriculture, Ain Shams University, Cairo, Egypt.

2. Institute of Plant Pathology, Agricultural Res. Center, Giza, Egypt.

ABSTRACT

Different chemical inducers namely, DL- $\beta$-aminobutyric ( $\beta A B A)$, salicylic acid (SA) and indole acetic acid (IAA) were used to induce resistance in wheat plants against leaf rust disease caused by Puccinia triticina Eriks under greenhouse conditions. Seedlings were sprayed by different concentrations of inducers at the second leaf stage (14 days old) and challenge inoculation by uredia was carried out at three leaf stage (19 days old).

All concentrations of the tested compound led to significant reduction in infection type and mean number of pustules on both tested wheat varieties i.e. resistant (Giza-168), and susceptible (Sids-1). DL- $\beta$-aminobutyric acid at $1000 \mu \mathrm{g} / \mathrm{ml}$ gave the best results in controlling leaf rust followed by the higher concentration of indole acetic acid and salicylic acid in descending order. All chemical inducers led to an increase of free phenols in both tested cultivars, but conjugated phenols were increased in the susceptible cv. (Sids-1) and decreased in resistance one (Giza$168)$. Wheat seedlings treated with $\beta A B A$ or IAA, and then challenge inoculation with Puccinia triticina, showed higher level of peroxidase activity. Meanwhile, the level of peroxidase in the resistant cultivar Giza-168 was higher in seedlings treated with IAA followed by $\beta A B A$ and $S A$. Cross sections of treated wheat leaves showed higher rate of lignification in the cell walls of xylem vessels due to $\beta A B A$ application as compared to non-treated leaves.

Data revealed that rust incidence was reduced at site of application ( $2^{\text {nd }}$ leaf), as well as at remote site ( $3^{\text {rd }}$ leaf). These results proved that these compounds could induce systemic acquired resistance in wheat plants against $P$.triticina.

Keywords: Wheat, leaf rust disease, Systemic acquired resistance, Peroxidase activity, Phenolic compounds, DL-3-aminobutric acid (BABA), Salicylic acid (SA) and Indole acetic acid (IAA).

\section{INTRODUCTION}

Wheat plants are suffering of many destructive diseases. Cereal rusts are the most serious diseases of cultivated plants resulting in losses equivalent to about $10 \%$ of the world grain crop (Sayre et al., 1998). Wheat leaf rust disease caused by Puccinia triticina Eriks, (Long et al., 1994 syn. P. recondita Roberge ex Desmaz. f. sp. tritici Eriks and Henn) is considered one of the most serious diseases in Egypt causing great losses in grain yield and quality (El-Daoudi, 1994).

Induced resistance is the phenomenon by which the plant can utilize the own defense mechanism to increase the level of resistance without changing plant genome (Kuć, 1982 and Van Loon, 1997). There are two types of induced resistance, local acquired resistance (LAR), which is limited at the 
site of induction, and systemic acquired resistance (SAR), which develops in plant tissues not directly exposed to induction (Kessmann et al., 1994; Deverall, 1995 and Lyon \& Newton, 1997). Several natural and synthetic chemical agents have been described as activators of defense - related processes when applied to plants. Some of these activators may have potential application in agriculture (Kessmann et al., 1994 and Yamaguchi, 1998). Certain chemicals, such as salicylic acid derivatives; 2, 6-dichloroisonicotinic acid (INA); benzothiadiazole (BTH) and $\beta$-aminobutyric acid ( $\beta A B A$ ) have been reported to induce resistance in cereal plants (Kogel et al., 1995; Görlach et al., 1996 and Stadnik \& Buchenauer, 1997). DL- $\beta$ aminobutyric (BABA) has been shown to induce plant defense against numerous pathogens as well as abiotic stresses. (Zimmerli et al, 2000 and Kuc, 2001). Less information is available on the activity of $\beta A B A$ against plant diseases caused by basidiomycetes (Amzalak and Cohen, 2007).

On the other hand, it was found that the growth regulator, indol-3- acetic acid (IAA), enhance wheat resistance against leaf rust disease (Sallam, Minaas, 1997). Salicylic acid (SA) is considered one of the key components of defense signal transduction inducing the full set of systemic acquired resistance genes (Maleck et al., 2000 and Von Rad et al., 2005 ).

In the present study, both a susceptible wheat cultivar (Sids-1) and a resistant one (Giza-168), were treated with different concentrations of DL- $\beta$ aminobutyric acid ( $\beta A B A)$; salicylic acid (SA) and indole acetic acid (IAA), to explore their effect on the leaf rust development and some physiological alterations occurred.

\section{MATERIALS AND METHODS}

The following experiments were conducted in the greenhouses and laboratories of Department of Plant Pathology, Faculty of Agriculture, Ain Shams University and Wheat Research. Section, Plant Pathology. Research. Institute. , ARC, Giza, Egypt. during seasons 2005 and 2006.

\section{Plant and fungal materials:}

Grains of the Egyptian wheat Triticum aestivum L. cvs. Giza-168 and Sids-1 were kindly obtained from Wheat Research. Section, Field Crop Institute, ARC, Giza, Egypt. Meanwhile, uredia of Puccinia triticina (race 77) were kindly provided by Wheat Res. Sec., Plant Pathol. Res. Instit. , ARC, Giza, Egypt.

\section{Induction of systemic resistance:}

The wheat Grains were sown in plastic pots $(9 \mathrm{~cm}$ diam), containing clay soil, at rate of 10 grains/pot. All cultural practices were precisely applied .Fourteen days old seedling (two leaves stage) were sprayed with tested chemical compounds, meanwhile control plants were sprayed only by distill water All trials were conducted in a complete randomized block design with five replicates. Five days later, seedlings (3 leaves stage) were inoculated by uredia of Puccinia triticina (race 77) as described by Tervet and Cassel, (1951).Ten wheat seedlings were rubbed gently between moisted fingers with tap water, then were brushing and shacking the original infected rusted 
seedlings over them. Inoculated plants were immediately sprayed again with tap water in order to induce initial dew on the plants. Finally, inoculated seedlings were kept in dark moist chambers at $18^{\circ} \mathrm{C}-20^{\circ} \mathrm{C}$ for $24 \mathrm{hr}$ to allow the rust spores to germinate. The inoculated seedlings were then transferred to their respective benches of the greenhouse and kept under observation for 12-15 days.

\section{Chemical inducers:}

Three chemical compound i.e. DL- $\beta$-aminobutyric acid (250-500$1000 \mu \mathrm{g} / \mathrm{ml})$, salicylic acid $(250-500-1000 \mu \mathrm{g} / \mathrm{ml})$ and indol-3-acetic acid $(25-$ $50-100 \mu \mathrm{g} / \mathrm{ml}$ ).were tested to evaluate their capabilities to induce resistance against Puccinia triticina in wheat seedlings.

\section{Disease assessment:}

The developed symptoms on the second and third rusted leaf were recorded as resistance $(R)$ or susceptible $(S)$ depending on the infection types (IT) according to Stakman et al., (1962) as presented in Table (1). The infection types, i.e. 0, 0; , I and 2 are considered to be resistant (R) while 3 and 4 are considered to be moderately susceptible (MS) and susceptible (S), respectively. The numbers of pustules per $\mathrm{cm} 2$ on the upper side of the leaves were counted as described by Parlevliet and Kuiper, (1977).

Table (1): Infection types of wheat leaf rust caused by Puccinia triticina (Stakman et al., 1962).

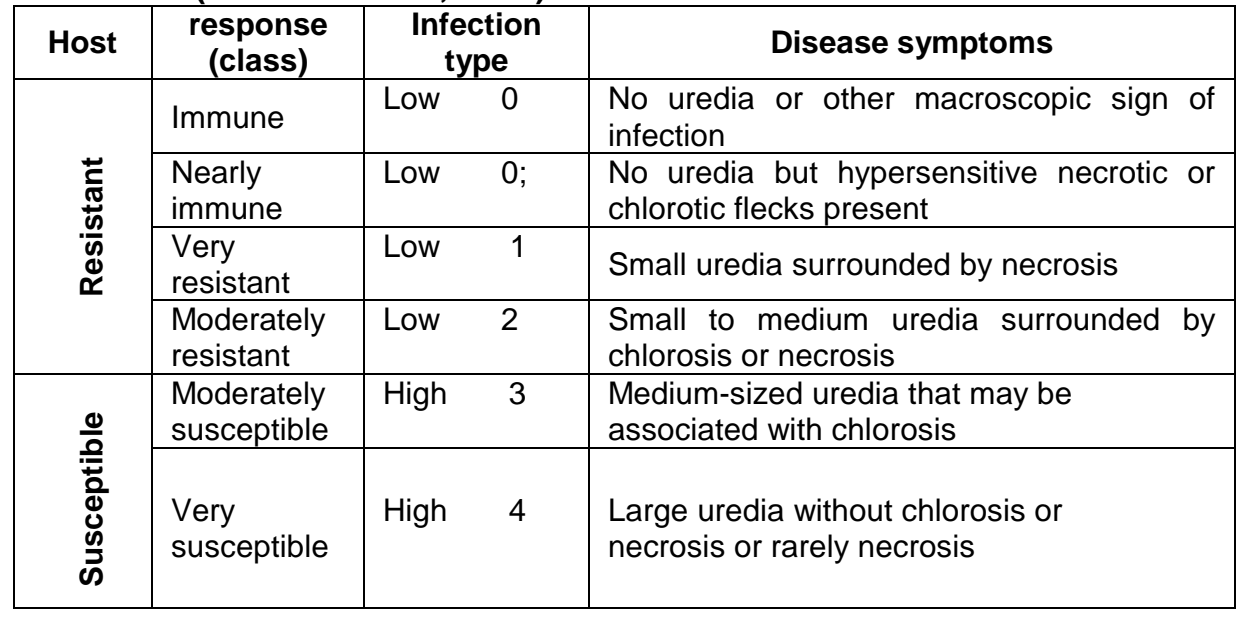

\section{Peroxidase Assay:}

Samples of the second leaves, sprayed with higher concentration of chemical inducers were used to determine the activity of peroxidase (PO). The extraction procedure was essentially based on the methods described by Biles and Martyn, (1993) as follow: $1 \mathrm{~g}$ of leaf tissue (30 days old) was collected, then treated by liquid nitrogen and ground in $2 \mathrm{ml}$ sodium phosphate buffer $(\mathrm{PH} 6.5,0.1 \mathrm{M})$ using mortar and pestle. Samples were transferred to Eppendorf tubes, and then centrifuged for $20 \mathrm{~min}$ at $12000 \mathrm{rpm}$ 
at $4^{\circ} \mathrm{C}$. The Peroxidase activity was directly determined of the crude enzyme extract according to a typical procedure Hammerschmidt et al.,(1982).

The reaction mixture consisted of $2.9 \mathrm{ml}$ of a $100 \mathrm{mM}$ sodium phosphate buffer $(\mathrm{pH} 6.0)$ containing $0.25 \%(\mathrm{v} / \mathrm{v})$ guaiacol (2- methoxy phenol) and $100 \mathrm{mM} \mathrm{H}_{2} \mathrm{O}_{2}$. The reaction was started by adding $100 \mu \mathrm{l}$ of the crude enzyme extract, then changes in absorbance at $470 \mathrm{~nm}$ were recorded for $3 \mathrm{~min}$. Enzyme activity was expressed as increase in absorbance $\min ^{-1} \mathrm{~g}$ 1 fresh weight.

\section{Determination of phenolic compounds:}

Phenolic compounds were extracted of wheat leaves after 15 days from inoculation by $P$. triticina according to the method described by Swain and Hillis, (1955).Leaf samples (1g) was mixed with $15 \mathrm{ml}$ of ethanol $80 \%$ and stored in a dark bottle at $4^{\circ} \mathrm{C}$ for $72 \mathrm{~h}$. Ethanol was daily changed, and then all were combined and filtered through filter paper for determination free, conjugated and total phenols according to the methods of folin-Denis as described by Swain and Hillis, (1955). The optical density of the color developed was measured at $725 \mathrm{~nm}$ using Unico UV-2100 Spectrophotometer.

\section{Sample preparation for light microscope.}

Samples of treated and not treated wheat leaves (sids-1) were collected 8 and 14 days after inoculation. Leaf segments were cut and immediately fixed in formalin - acetic acid - ethanol $70 \%$ (FAA) for $24 \mathrm{~h}$, and then dehydrated in ascending ethanol. Paraffin wax was infiltrated and samples were embedded (Johanson, 1940). Cross - sections were microtomed $(6-8 \mu \mathrm{m})$ and mounted to glass slides and stained with safranin - fast green schedule (Sander, 1993). Sections were examined and photographed with a light microscope (Leica DM 2500).

\section{Statistical analysis}

Data were statistically analyzed by analysis of variance (ANOVA), by using statistical analysis cycle (SAS) followed by Duncan's multiple range test (Duncan, 1955) at ( $\mathrm{P} \leq 0.05)$.

\section{RESULTS}

\section{Effect of inducers on disease assessment parameters}

The effect of spraying wheat seedlings with different chemical inducers i.e. DL- $\beta$-aminobutyric acid (BABA), salicylic acid (SA), and indole acetic acid (IAA) on infection type (IT) and mean number of pustules/cm² (No.p. $/ \mathrm{cm}^{2}$ ) was determined.

Data in Tables (2 \& 3 ) indicated that, all concentrations of the tested compounds led to a reduction in both infection type (IT) and mean number of pustules $/ \mathrm{cm}^{2}$ (No.p. $/ \mathrm{cm}^{2}$ ) when measured at the site of application ( $2^{\text {nd }}$ leaf). The highest reduction was obtained by spraying $\beta A B A$ followed by indole acetic acid and salicylic acid treatments in descending order. Data presented in Table (2), illustrate that, treatment of $\beta A B A$ at the higher concentration $(1000 \mu \mathrm{g} / \mathrm{ml})$ on Sids-1 seedlings, clearly reduced the infection type $(0 ;)$ and 
followed by IAA and SA $(0 ;, 1$ and 2,3$)$ on compared with control plants (4).The same trend of reduction was also observed for the number of pustules/area. Treatment of $\beta A B A$ clearly decreased the number of pustules $\left(10.4 / \mathrm{cm}^{2}\right)$, followed by treatment of IAA and SA treatments (12.4 \& 20.2), compared with control plants $\left(25.0 / \mathrm{cm}^{2}\right)$. Infection type and number of pustules/area on Giza-168 (resistant cultivar), showed almost similar trend during the growth season of 2005. Meantime, obtained results during the growth season 2006 (Table, 3) also revealed that the higher concentration of application, the greater reduction in disease incidence. The aforementioned results (Tables, $2 \& 3$ ), clearly proved the occurrence induction of resistance at the site of inducer application (second leaf) .Meantime, data in Table (3), indicated that the induction of resistance was obviously extended to a remote site ( $3^{\text {rd }}$ leaf), which gain almost similar trend of effect.

Table (2): Effect of spraying wheat seedlings with chemical inducers on leaf rust (Puccinia triticina) disease assessment on susceptible (Sids-1) and resistant (Giza-168) wheat cultivars during the season 2005.

\begin{tabular}{|c|c|c|c|c|c|c|c|c|c|}
\hline \multirow{3}{*}{ Treatments } & \multirow{3}{*}{ sConcentrations } & \multicolumn{4}{|c|}{ Sids-1 } & \multicolumn{4}{|c|}{ Giza-168 } \\
\hline & & \multicolumn{2}{|c|}{$\begin{array}{c}\left(2^{\text {nd }}\right) \\
\text { At site }\end{array}$} & \multicolumn{2}{|c|}{$\begin{array}{c}\left(3^{\text {rd }}\right) \\
\text { At remote } \\
\text { site }\end{array}$} & \multicolumn{2}{|c|}{$\begin{array}{c}\left(2^{\text {nd }}\right) \\
\text { At site }\end{array}$} & \multicolumn{2}{|c|}{$\begin{array}{l}\left(3^{\text {rd }}\right) \\
\text { At remote } \\
\text { site }\end{array}$} \\
\hline & & NP & IT & NP & IT & NP & IT & NP & IT \\
\hline Control & & $25.0^{a}$ & 4 & $30.0^{a}$ & 3,4 & $22.0^{a}$ & $3-4$ & $27.0^{a}$ & 3 \\
\hline \multirow{3}{*}{$\beta A B A$} & $250 \mu \mathrm{g} / \mathrm{ml}$ & $17.9^{\mathrm{bcd}}$ & 1 & $15.8^{\mathrm{bcd}}$ & $0 ;, 1$ & $15.0^{\mathrm{bcd}}$ & $0 ;, 1$ & $12.1^{\text {bcde }}$ & 1 \\
\hline & $500 \mu \mathrm{g} / \mathrm{ml}$ & $15.3^{\mathrm{cd}}$ & $0 ;, 1$ & $12.0^{\mathrm{cd}}$ & $0 ;, 1$ & $12.7^{\mathrm{cd}}$ & $0 ; 1$ & $10.5^{\text {de }}$ & 0 \\
\hline & $1000 \mu \mathrm{g} / \mathrm{ml}$ & $10.4^{\mathrm{e}}$ & 0 & $8.3^{e}$ & 0 & $9.2^{\mathrm{e}}$ & 0 & $7.9^{f}$ & 0 \\
\hline \multirow{3}{*}{ SA } & $250 \mu \mathrm{g} / \mathrm{ml}$ & $23.2^{\mathrm{ab}}$ & 3,4 & $20.0^{\mathrm{b}}$ & 3 & $21.0^{a b}$ & 3,4 & $17.5^{b}$ & 3 \\
\hline & $500 \mu \mathrm{g} / \mathrm{ml}$ & $21.5^{\mathrm{abc}}$ & 3 & $18.0^{\mathrm{bc}}$ & 2,3 & $18.3^{a b c}$ & 2,3 & $16.4^{b c}$ & 2,3 \\
\hline & $1000 \mu \mathrm{g} / \mathrm{ml}$ & $20.2^{\mathrm{abc}}$ & 2,3 & $16.5^{\mathrm{bcd}}$ & 2 & $17.5^{\mathrm{abcd}}$ & 2 & $15.2^{\mathrm{bcde}}$ & 2 \\
\hline \multirow{3}{*}{ IAA } & $250 \mu \mathrm{g} / \mathrm{ml}$ & $18.5^{\mathrm{abcd}}$ & 2 & $15.4^{\mathrm{bcd}}$ & 1,2 & 16. $\wedge^{\mathrm{abcd}}$ & 2 & $14.2^{\mathrm{bcde}}$ & 1,2 \\
\hline & $500 \mu \mathrm{g} / \mathrm{ml}$ & $16.5^{\mathrm{bcd}}$ & 1,2 & $13.0^{\mathrm{bcd}}$ & 1 & $14.0^{\mathrm{cd}}$ & 1 & $11.1^{\text {cde }}$ & 1 \\
\hline & $1000 \mu \mathrm{g} / \mathrm{ml}$ & $12.4^{d}$ & $0 ; 1$ & $10.1^{d}$ & $0 ;, 1$ & $10.8^{d}$ & $0 ;, 1$ & $8.9^{e}$ & $0 ;, 1$ \\
\hline LSD & & 7.17 & & 8.397 & & 7.08 & & 6.61 & \\
\hline
\end{tabular}

NP: Mean No. of pustules $/ \mathrm{cm}^{2}$, IT: infection type, $\beta A B A$ : DL- $\beta$-aminobutyric acid, SA: salicylic acid, and IAA: Indole acetic acid. 
Thabet, Marian. S. et al.

Table (3): Effect of spraying wheat seedlings with chemical inducers on leaf rust (Puccinia triticina) disease assessment on susceptible (Sids-1) and resistant (Giza-168) wheat cultivars during the season 2006.

\begin{tabular}{|c|c|c|c|c|c|c|c|c|c|}
\hline \multirow{3}{*}{ Treatments } & \multirow[t]{3}{*}{ Concentrations } & \multicolumn{4}{|c|}{ Sids-1 } & \multicolumn{4}{|c|}{ Giza-168 } \\
\hline & & \multicolumn{2}{|c|}{$\begin{array}{c}\left(2^{\text {nd }}\right) \\
\text { At site }\end{array}$} & \multicolumn{2}{|c|}{$\begin{array}{l}\left(3^{\text {rd }}\right) \\
\text { At remote } \\
\text { site }\end{array}$} & \multicolumn{2}{|c|}{$\begin{array}{c}\left(2^{\text {nd }}\right) \\
\text { At site }\end{array}$} & \multicolumn{2}{|c|}{$\begin{array}{c}\left(3^{\text {rd }}\right) \\
\text { At remote } \\
\text { site }\end{array}$} \\
\hline & & NP & IT & NP & IT & NP & IT & NP & IT \\
\hline Control & & $15.46^{\mathrm{a}}$ & 4 & $20.0^{a}$ & 4 & $11.96^{\mathrm{a}}$ & 3,4 & $14.33^{a}$ & 4 \\
\hline$\beta A B A$ & $1000 \mu \mathrm{g} / \mathrm{ml}^{-1}$ & $7.28^{b}$ & $0 ;, 1$ & $4.00^{c}$ & 0 & $6.23^{b}$ & $0 ;, 1$ & $3.80^{c}$ & $0 ;, 1$ \\
\hline SA & $1000 \mu \mathrm{g} / \mathrm{ml}^{-1}$ & $10.19^{b}$ & 3,4 & $10.0^{\mathrm{b}}$ & 3 & $9.23^{\mathrm{ab}}$ & 3 & $8.40^{b}$ & 2,3 \\
\hline IAA & $100 \mu \mathrm{g} / \mathrm{ml}^{-1}$ & $7.86^{\mathrm{b}}$ & $0 ;, 1,2$ & $5.85^{\mathrm{bc}}$ & $0 ; 1$ & $7.93^{\mathrm{ab}}$ & 1,2 & $5.11^{b c}$ & 1,2 \\
\hline LSD & & 3.70 & & 5.45 & & 4.90 & & 4.39 & \\
\hline
\end{tabular}

NP: Mean No. of pustules $/ \mathrm{cm}^{2}$, IT: infection type, $\beta A B A: D L-\beta$-aminobutyric acid, SA: salicylic acid, and IAA: Indole acetic acid.

\section{Effect of different inducers on Peroxidase (PO) activity:}

The activity of Proxidase (PO) was determined at site of inducers application (the $2^{\text {nd }}$ leaf) of both the susceptible cultivar (sids-1) and the resistant one (Giza-168).

Enzyme content was detected for treated plants, either inoculated or noninoculated with Puccinia triticina. Peroxidase analysis of infected plants showed higher activity as compared to healthy wheat seedlings (Fig, 1a \& b). Similar trend was obtained for both the resistant and susceptible wheat cultivars. Spraying wheat seedlings with different inducers clearly increased the PO activity. The highest increase was detected when sprayed with IAA and $\beta$-ABA (Fig, 2a\&b) On the other hand, the non-infected resistant seedlings gained higher PO activity due to treating with SA (Fig, $3 a \& b$ ).

\section{Effect of different inducers on phenolic compounds:}

Free, conjugated and total phenols were determined at site of inducers application ( $2^{\text {nd }}$ leaf). The free phenols of both wheat cultivars (Sids1 \& Giza-168) were increased due to applying different inducers (Table, 4).The resistant cultivar (Giza-168) showed higher content of the conjugated phenols as compared to that of susceptible cultivar (sids-1). Results in Table (4) also indicate that inducers increased the content of conjugated phenols of Sids-1 cultivar. On the other hand, phenolic compounds of Giza-168 seedlings were clearly decreased due to inducers application. The abovementioned trend was recorded in both healthy and infected wheat seedlings. Consequently, the total content of phenolic compounds, showed a similar trend to that obtained with the conjugated phenols for both infected and healthy wheat seedlings of the two cultivars under investigation. 
Sids-1
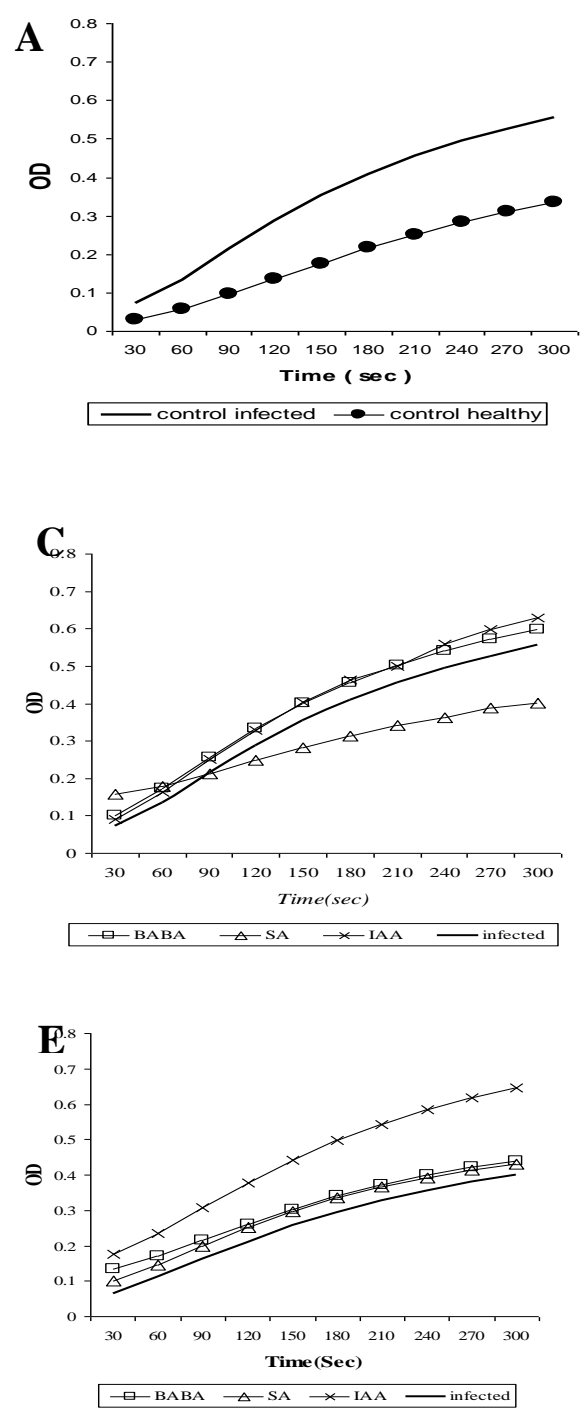

Giza-168
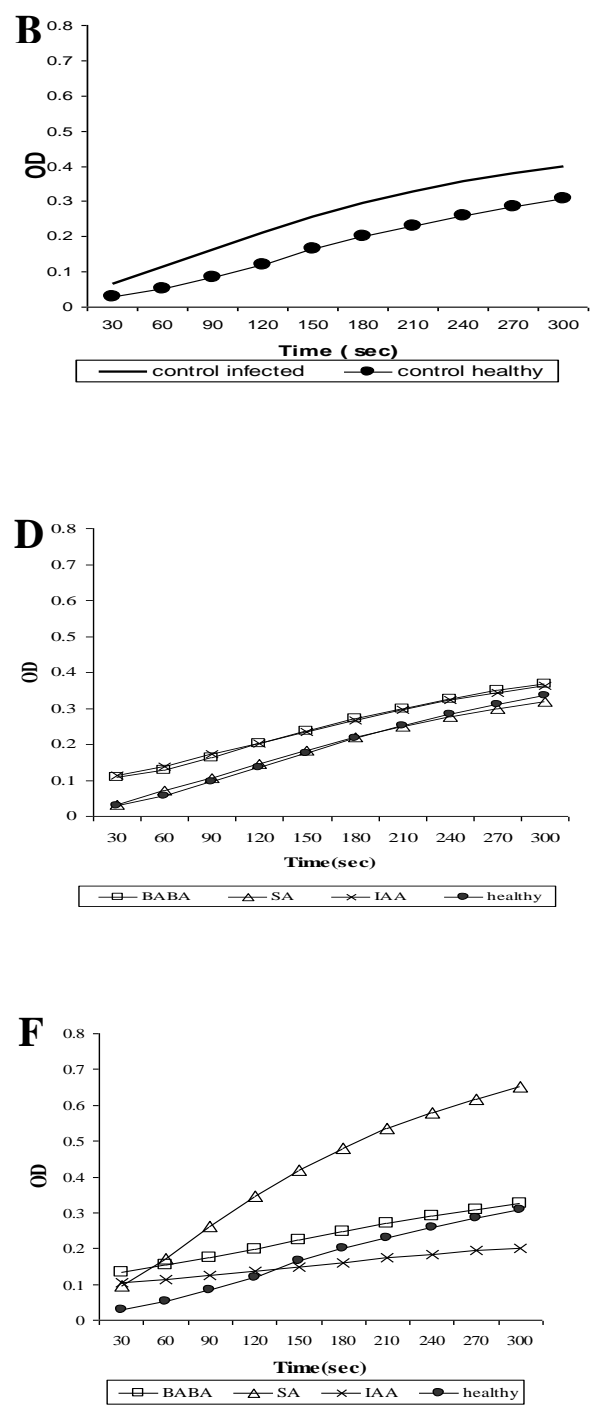

Fig (1): Effect of spraying different inducers on Peroxidase activity in wheat leaves, susceptible cultivar (Sids-1) and resistant cultivar (Giza-168). (A) Healthy and infected control leaves of sids-1. (B) Healthy and infected control leaves of Giza-168. (C) Treated and inoculated leaves of sids-1. (D) Treated non- inoculated leaves of (sids-1). (E) Treated and inoculated leaves of (Giza-168). (F) treated non- inoculated of (Giza-168). 
Thabet, Marian. S. et al.

Table (4): Phenolic compounds of healthy and infected wheat seedlings (susceptible cultivar), as determined at the site of inducers application ( $2^{\text {nd }}$ leaf), 15 days after Puccinia triticina infection.

\begin{tabular}{|l|l|c|c|c|c|c|c|}
\hline \multirow{2}{*}{ Treatments } & \multirow{3}{*}{ Concentrations } & \multicolumn{5}{|c|}{ Sids-1 cV. } \\
\cline { 3 - 7 } & & \multicolumn{3}{|c|}{ Healthy } & \multicolumn{3}{|c|}{ Infected } \\
\cline { 3 - 7 } & & $\mathbf{F}$ & $\mathbf{C}$ & $\mathbf{T}$ & $\mathbf{F}$ & $\mathbf{C}$ & $\mathbf{T}$ \\
\hline Control & & $22.71^{\mathrm{c}}$ & $19.61^{\mathrm{b}}$ & $42.32^{\mathrm{b}}$ & $12.15^{\mathrm{b}}$ & $19.92^{\mathrm{b}}$ & $32.07^{\mathrm{e}}$ \\
\hline BABA & $1000 \mu \mathrm{g} \mathrm{/ml^{-1 }}$ & $25.21^{\mathrm{bc}}$ & $28.65^{\mathrm{ab}}$ & $53.86^{\mathrm{a}}$ & $18.90^{\mathrm{b}}$ & $28.79^{\mathrm{ab}}$ & $47.69^{\mathrm{bcd}}$ \\
\hline SA & $1000 \mu \mathrm{g} / \mathrm{ml}^{-1}$ & $27.35^{\mathrm{ab}}$ & $22.89^{\mathrm{b}}$ & $50.24^{\mathrm{ab}}$ & $30.60^{\mathrm{a}}$ & $27.53^{\mathrm{b}}$ & $58.13^{\mathrm{bc}}$ \\
\hline IAA & $100 \mu \mathrm{g} / \mathrm{ml}^{-1}$ & $25.26^{\mathrm{bc}}$ & $25.04^{\mathrm{b}}$ & $50.30^{\mathrm{ab}}$ & $30.42^{\mathrm{a}}$ & $29.18^{\mathrm{ab}}$ & $59.60^{\mathrm{ab}}$ \\
\hline
\end{tabular}

F: free phenolic compound, C: conjugated phenolic, T: Total phenol, $\beta A B A$ :

DL- $\beta$-aminobutyric acid, SA: salicylic acid, and IAA: Indole acetic acid

Table (5): Phenolic compounds of healthy and infected wheat seedlings (resistant cultivar), as determined at the site of inducers application ( $2^{\text {nd }}$ leaf), 15 days after Puccinia triticina infection.

\begin{tabular}{|c|c|c|c|c|c|c|c|}
\hline \multirow{3}{*}{ Treatments } & \multirow{3}{*}{ Concentrations } & \multicolumn{6}{|c|}{ Giza-168 cv. } \\
\hline & & \multicolumn{3}{|c|}{ Healthy } & \multicolumn{3}{|c|}{ Infected } \\
\hline & & $\mathbf{F}$ & C & $T$ & $\mathbf{F}$ & C & $\mathbf{T}$ \\
\hline Control & & $13.2^{b}$ & $47.66^{\mathrm{a}}$ & $60.86^{a b}$ & $14.79^{b}$ & $45.02^{\mathrm{a}}$ & $59.82^{\mathrm{abc}}$ \\
\hline BABA & $1000 \mu \mathrm{g} / \mathrm{ml}^{-1}$ & $22.37^{a}$ & $42.20^{\mathrm{ab}}$ & $64.58^{a}$ & $24.28^{a}$ & $31.85^{\mathrm{bc}}$ & $56.13^{a b c d}$ \\
\hline SA & $1000 \mu \mathrm{g} / \mathrm{ml}^{-1}$ & $23.17^{a}$ & $26.70^{c}$ & $49.87^{d c}$ & $26.64^{a}$ & $20.68^{c}$ & $47.32^{d}$ \\
\hline IAA & $100 \mu \mathrm{g} / \mathrm{ml}^{-1}$ & $26.64^{a}$ & $25.23^{c}$ & $51.87^{\mathrm{bcd}}$ & $24.92^{\mathrm{a}}$ & $23.69^{c}$ & $48.62^{d}$ \\
\hline
\end{tabular}

F: free phenolic compound, C: conjugated phenolic, T: Total phenol, $\beta A B A$ : DL- $\beta-$ aminobutyric acid, SA: salicylic acid, and IAA: Indole acetic acid

\section{Microscopic features.}

Cross sections of treated and non-treated wheat leaves (susceptible or resistant cultivar) were taken at 8 and 14 days after inoculation by Puccinia triticina. A higher lignification rate of deposition was markedly observed due to inducers application. The highest rate of lignification was obtained when seedlings treated with $(1000 \mu \mathrm{g} / \mathrm{ml})$ of $\beta A B A(F i g ~ 2)$.

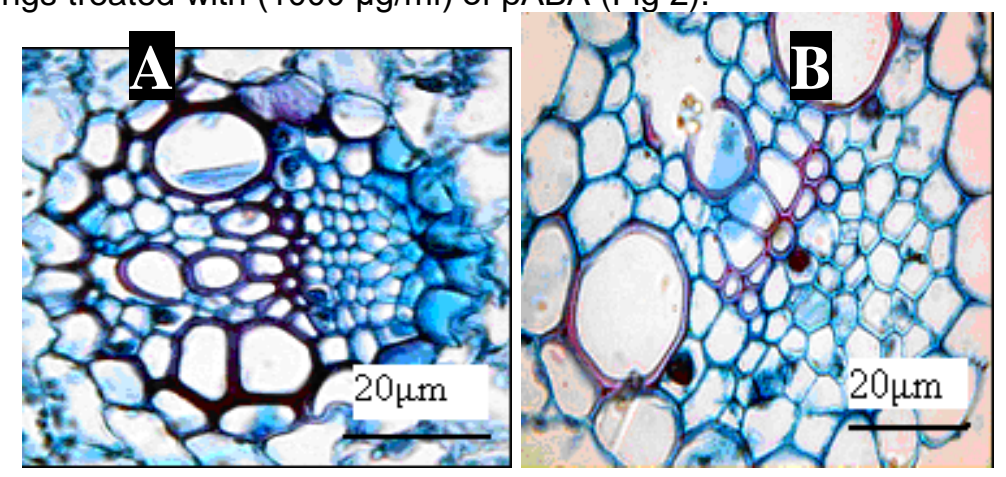

Fig (4): light micrographs of cross sections in wheat leaves cv.sids-1, illustrating the higher rate of lignification in the cell walls of vascular bundle contents due to $\beta A B A$ application $(A)$, as compared to non-treated leaves (B). 


\section{DISCUSSION}

Systemic acquired resistance is the phenomenon that, the plant can utilize its own defense mechanism to increase the level of resistance without changing plant genome which may involve the activation of more than one biochemical pathway (Kuc, 1982 and Van Loon, 1997). Three chemical compounds ( $\beta$-ABA; SA and IAA) were used to induce systemic resistance in wheat seedlings against leaf rust disease caused by Puccinia triticina. the obtained data clearly indicated that leaf rust symptoms were markedly reduced due to spraying with the three tested inducers at both the application site ( $2^{\text {nd }}$ leaves) as well as at remote site ( $3^{\text {rd }}$ leaf). This phenomenon, systemic acquired resistance (SAR), may be attributed to signal transduction from sight of application to non treated sites (Kessmann et al., 1994).

The results of this study showed that, all concentrations of the tested compounds led to a reduction in both infection type (IT) and mean number of pustules $/ \mathrm{cm}^{2}$ on both susceptible and resistant wheat cultivar in two seasons (2005 and 2006). The highest reduction was obtained by spraying BABA followed by IAA and SA, in descending order compared with non-treated seedlings. In the field of using $B A B A$ as inducer, similar trend was also reported by (El-Deeb, 1999 and Amzalak \& Cohen, 2007). The mode of action of $\beta A B A$ is not known because the reactions induced depend not only on the pathosystem, but also on the application method (Cohen, 2001 and Silue et al., 2002).Induction of resistance due to spraying $\beta A B A$, IAA and SA may be attributed to different factors affecting plant resistance. Among these factors pathogenesis related proteins, peroxidase, $\beta$ 1, 4-glucanase and chitinase which actively accumulated in immunized plants (Dann et al., 1998 and Owen et al., 2002).

Peroxidase (PO) is one of the most important enzymes in plants, mainly due to its involvement in so many molecular, physiological and morphological events in the plants life cycle. This enzyme localizes in different sites within plant cell (Hiraga et al., 2001) It is well known catalysis the oxidation of a wide variety of substrates, using $\mathrm{H}_{2} \mathrm{O}_{2}$ such as a phenol which plays a considerable role in lignin synthesis (Goldberg et al., 1987). Results of the present study indicated that spraying wheat seedlings with $B A B A$ \& IAA, led to an increase of PO activity compared with untreated infected ones. Higher PO activities in were obtained in wheat seedlings treated with inducers and infected with P.triticina compared with healthy ones. The susceptible seedlings (sids-1) showed higher activity than that of the resistant one (Giza-168). Similar trend of results was also detected by Mohammadi and Kazemi, (2002).

Phenols in plants are well-known to play a role as antifungal, antibacterial and antiviral compounds (Sivaprakasan \& Vidhyasekaran, 1993; Rengel et al., 1994 and Gogoi et al., 2001). Obtained results revealed that the resistant cultivar (Giza-168) showed higher content of the conjugated phenols compared with that of susceptible cultivar (Sids-1). Spraying with chemical inducers increased the content of conjugated phenols of Sids-1 cultivar, while in Giza-168 cultivar, it was markedly decreased. The 
abovementioned trend was recorded in both healthy and infected wheat seedlings. Menden et al., (1994) have also found that free phenols were increased due to spraying different inducers. Conjugated phenols increased in highly susceptible cultivar (Sids-1) and decreased in resistant ones (Giza 168). The bound phenolic acids which accumulate in cells undergoing a hypersensitive response, may play a role in resistance of wheat to the leaf rust fungus. Similar findings were also reported by Southerton \& Deveral, (1990). This phenomenon may illustrate the reasons of increasing free phenols in both cultivars. The increase of free phenols of the susceptible cultivar (Sids-1) may be attributed to the de novo synthesis of phenols. However, the resistant cultivar (Giza -168), showed an increase of free phenols. On the other hand, it was clearly observed that conjugated phenols were sharply decreased in seedlings treated by inducing agents. This finding may attribute to increased activity of glycosidase due to inducers application.

In the presence of $\mathrm{H}_{2} \mathrm{O}_{2}$ and peroxidases, phenolic compounds can bind to certain polysaccharides and glycoproteins to form gels which can be accumulated in the cell wall and act as an efficient physical barrier this may be correlated to the higher rate of lignifications due to treatment with different chemical inducers. (Fry, 1986 and Gregerson et al., 1997). Induced lignification is accompanied by an increase in the activity of the key enzymes of the phenylpropanoid pathway such as phenylalanine ammonia-lyase (PAL), cinnamyl alcohol dehydrogenase (CAD) and peroxidases (POX) (Nicholson \& Hammerschmidt, 1992). Phenylalanine ammonia-lyase (PAL) is the initial gateway enzyme in phenolic compound biosynthesis, and therefore it is critical in determining flux through the phenylpropanoid pathway and the production rate of phenolic compounds (Whetten \& Sederoff, 1995 and Zhang et al., 1997).

Cross sections of wheat leaves revealed a higher lignification rate in the vascular bundles Lignin serves as a matrix around the polysaccharide components of some cell walls, it increases the mechanical resistance of the tissue providing additional rigidity and compressive strength as well as rendering the walls hydrophobic and water impermeable. Cells that especially accumulate lignin, such as xylem elements and sclerenchyma, show frequently further cell wall modifications, such as secondary cell wall thickenings, (Monties, 1989 and Whetten \& Sederoff, 1995).

\section{REFERENCES.}

Amzalek, E. and Y. Chen. (2007). Comparative efficacy of systemic acquired resistance inducing compounds against rust infection in sunflower plants. Phytopathology, 97:179-186.

Biles, C.L and R.D. Martyn. (1993). Peroxidase, polyphenoloxidase and shikimate dehydrogenase isozymes in relation to tissue type, maturity and pathogen induction of watermelon seedling. Plant Physiol. Biochem. 31:499-506.

Cohen, Y. (2001). The BABA story of induced resistance. Phytoparasitica 29: 375-378. 
Dann, E.; B. Diers.; J. Byrum and R. Hammerschmidt. (1998). Effect of treating soybean with 2, 6 dichloroisonicotinic acid (INA) and benzothiadiazole (BTH) on seed yield and the level of disease caused by Sclerotinia sclerotiorum in field and greenhouse studies. Eur. J. Plant Pathol. 104:271-278.

Deverall, B. J. (1995). Plant protection using natural defense systems of Plant. Adv. Plant Pathol. 11:211 - 228.

Duncan, B.D. (1955). Multiple ranges and multiple F test. Biometric, 11: 1-42.

El-Daoudi, Y.H.; O.F. Mamluk.; E. Bekele.; Enayat, H. Chanem.; M.B. Solf and Shafik, Ikhlas. (1994). Preliminary results for leaf and stem rust of wheat, their prevelence and resistance in the Nile Valley Countries and Yeman Fifth Arab cong. Plant.Prot.,FezMorocco,Nov.27-Des.2( Abstr).

EL-Deeb, S.H. (1999). Inducing resistance of wheat plants against powdery mildew and leaf rust. Egypt, J. Appl. Sci., 14: 44-59.

Fry, S.C. (1986). Cross-linking of matrix polymers in the growing cell walls of angiosperms. Annu. Rev. Plant Physiol. 37:165-186.

Gogoi, R.; D.V. Singh and K.D. Srivastava, (2001). Phenols as a biochemical basis of resistance in wheat against karnal bunt. Plant Pathol, 50:470-476.

Goldberg, R.; M. Liberman.; C. Mathieu.; C.M. Pierron and A.M. Catesson. (1987). Development of epidermal cell wall peroxidase along the bean hypocotyls: Possible involvement in the cell wall stiffening process. J. Exp. Bot. 38:1378-1390.

Gorlach, J.; S. Volrath.; G. Knauf-Beiter.; G. Hengy.; U. Beckhove.; K.H. Kogel.; M. Oostendorp.; T. Staub.; E. Ward.; H. Kessmann and J. Ryals. (1996) Benzothiadiazole, anovel class of inducers of systemic acquired resistance, activates gene expression and disease resistance in wheat. The Plant Cell, 8:629-643

Gregersen, P.L.; H. Thordal-Christensen.; H. Förster and D.B. Collinge. (1997). Differential gene transcript accumulation in barley leaf epidermis and mesophyl in response to attack by Blumeria graminis $f$. sp. hordei (syn. Erysiphe graminis f. sp. hordei). Physiol. Mol. Plant Pathol. 51: 85-97.

Hammerschmidt, R.; E. M. Nuchles and J. Kuc. (1982). Association of enhanced peroxidase activity with induced systemic resistance of cucumber to Colletotrichum lagenariam Physiol.Plant Pathol. 20:73-82.

Hiraga, S.; K. Sasaki.; H. Ito.; Y. Ohashi and H. Matsui. (2001) A large family of class III plant peroxidases. Plant Cell Physiol 42:462-468.

Johanson, D.A. (1940). Plant microtechnigue. McGraw-Hill, Book Company, Inc New York and London.523pp.

Kessmann, H.; T. Staub.; C. Hofmann.; T. Maetzke.; J. Herzog.; E. Ward.; S. Ukness and J. Ryals. (1994). Induction of systemic acquired resistance in plants by chemicals. Annu. Rev. Phytopathol.32:439-459.

Kogel, K.H.; B. Ortel.; B. Jarosch.; R. Atzorn.; R. Schiffer and C. Wasternack. (1995) Resistance in barley against the powdery mildew fungus (Erysiphe graminis f.sp. hordei) is not associated with enhanced levels of endogenous jasmonates. Eur J. Plant Pathol, 101: $319-332$. 
Kuc, J. (1982). Induced immunity to plant disease. BioScience 32:854-860.

Kuc, J. (2001). Concepts and direction of induced systemic resistance in plants and its application. Eur. J. Plant Pathol. 107:7-12.

Long, D.L.; A.P. Roelfs.; K.J. Leonard and J.J. Roberts. (1994).Virulence and diversity of Puccinia recondite f.sp. tritici in the United states in 1992. Plant Dis.78:901-906.

Lyon, G.D and A.C. Newton. (1997). Do resistance elicitors offer new opportunities in integrated disease control strategies? Plant Pathol. 46: 636-641.

Maleck, K.; A. Levine.; T. Eulgem.; A. Morgan.; J. Schmid.; K.A. Lawton.; J.L. Dangl and R.A. Dietrich. (2000). The transcriptase of Arabidopsis thaliana during systemic acquired resistance. Nat. Genet. 26:403-410.

Menden, B.P.; C. Kaum.; B.M. Moerschbacher.; M. Geibel.; D. Treutter and W. Feuchet. (1994). Phenolic acids in the resistance of wheat to stem rust. Acta-Horticulture, 381: 557-560.

Mohammadi, M and H. Kazemi. (2002). Change in Peroxidase and polyphenoloxidase activities in susceptible and resistant wheat heads inoculated with Fusarium graminearum and induced resistance. Plant Sci. 162: 491-498.

Monties, B. (1989). Lignin In: Methods in Plant Biochemistry. Vol.1. (Dey, P.M. and J.B. Harborne, eds). Academic Press. New York. Pp.113158.

Nicholson, R.L and R. Hammerschmidt. (1992). Phenolic compounds and their role in disease resistance. Annu. Rev. of Phytopathol.30: 369389.

Owen, K.J.; C.D. Green and B.J. Deveral. (2002). A benzothiadiazole applied to foliage reduces development and egg deposition by Meloidogyne spp. in glasshouse-grown grapevine roots.Austr.Plant Pathol.31:47-53.

Parlevliet, J.E. and H.J. Kuiper. (1977). Resistance of some barley cultivars to leaf rust, Puccinia hordei; polygentic, partial resistance hidden by monogenic hypersensitivity. Neth. J. Plant Pathol. 83: 85-89.

Rengel, D.; R. Graham and J. Pedler. (1994). Time course of biosynthesis of phenolics and lignin in roots of wheat genotypes differing in manganese efficiency and resistance to take-all fungus. Ann. Bot. 74: 471- 477.

Sallam, Minaas. (1997). Studies on leaf rust of wheat in Egypt. Ph.D.Thesis, Fac. Agric., Zagazig Univ., Egypt. 119pp.

Sander, J. F (1993). Biochemisch- physiologische Ursachen der durch die stickstoffernährug modiizierten Anfälligkeit des weizens (Triticum aestivum L). gegenüber dem Echten Mehitau (Erysiphe graminis DC f.sp. tritici Marchai) (PhD thesis). Culliververlag, Göttinen.148p.

Sayre, K. D., R. P. Singh, J. Huertaespino, and S. Rajaram, (1998) Genetic progress in reducing losses to leaf rust in CIMMYT-derived Mexican spring wheat cultivars. Crop Sci. 38:654-659.

Silue, D.; E. Pajot and Y. Cohen. (2002). Induction of resistance to downy mildew (Peronospora parasitica) in caulinower by DL- $\beta$-amino-nbutanoic acid (BABA). Plant Pathol. 51:97-102. 
Sivaprakasan, K and P. Vidhyasekaran. (1993). Phenylalanine ammonialyase gene for crop disease management. In: Genetic Engineering, Molecular Biology and Tissue Culture for Crop Pest and Disease Management. Vidhyasekaran P, ed. Daya Publishing House Delhi, India: pp. 113-122.

Southerton, S.G and B.J. Deverall (1990).Changes in phenolic acid levels in wheat leaves expressing resistance to Puccinia recondite f. sp. tritici. Physiol. Mol. Plant Pathol. 37: 437- 450.

Stadnik, M and H. Buchenauer (1997). Screening for inducers of resistance to Powdery mildew in winter wheat. In: Proceedings of the Conference on Protection of Cereal Crops against Harmful organisms, Tvaruzek L. (ed.). Kromeriz 1996, pp. 115-118.

Stakman, E.C.; D.M. Stewart and W.Q. Loegering, (1962). Identification of physiologic races of Puccinia graminis var: tritici. Agric. Res. Science. E617. USDA: Washington DC.

Swain, T. and W.E. Hallis. (1955). The phenolic constituents of Prunus domestica.l. The quantative analysis of phenolic constituent. J. Sci .Food \& Agaric. 10:63-68.

Tervet, I. and R.C. Cassel. (1951). The use of cyclone separation in race identification of cerealrustes. Phytopathology, 41: 282-285.

Steiner, U and F. Schonbeck. (1995). Induced disease resistance in monocots, in: Induced Resistance to Disease in Plants, R. Hammerschmidt, J. Kuc' (Eds.), Kluwer Academic Publishers, Dordrecht, The Netherlands, pp. 86-110.

Van Loon, L.C. (1997). Induced resistance in plants and the role of pathogenesis- related proteins. Eur. J. Plant Pathol. 103:753-765.

Von Rad, U.; M.J. Mueller and J. Durner. (2005). Evaluation of natural and synthetic stimulants of plant immunity by microarray technology. New Phytol. 165:191-202.

Whetten, R. and R. Sederoff. (1995). Lignin Biosynthesis. The Plant Cell.7:1001-1013.

Yamaguchi, I. (1998). Activators of systemic acquired resistance. In: Fungicidal activity: Chemical and biological approaches to plant protection. Hutson D.H. Miyamoto J., eds. New York: Wileyev \& S611s Inc., pp. 193-219.

Zhang, L.; M.P. Robbins.; T.L.W. Carver.; R.J. Zeyen. (1997). Induction of phenylpropanoid gene transcripts in oat attacked by Erysiphe graminis at $208 \mathrm{C}$ and $108 \mathrm{C}$. Physiol. Mole. Plant Pathology 51: 15-33.

Zimmerli, L.; J. P. Metraux and B. Mauch-Mani. (2001). ß-aminobutyric acidinduced protection of Arabidopsis against heterotrophic fungus Botrytis cinerea. Plant Physiol. 126:517-523. 


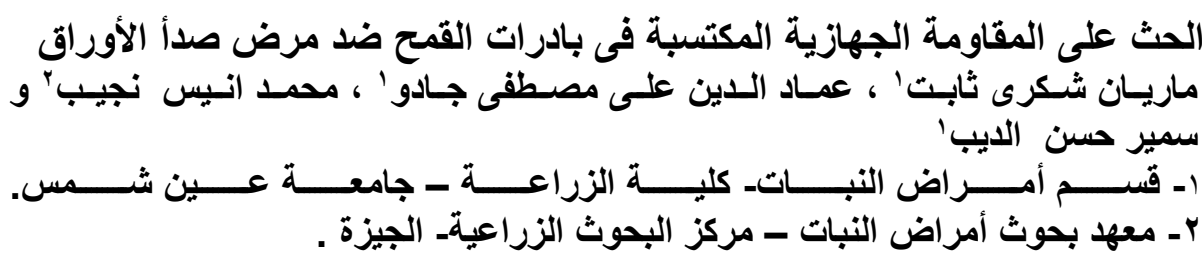

اجرى هذا البحث لدرسة كفاءةة بعض المو اد الكيميائية المختلفة على إكساب بادرات اتلمات القمح مقاومة ضد مرض صدأ الأوراق المتسبب عن فطر

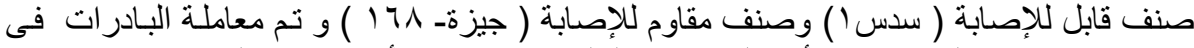

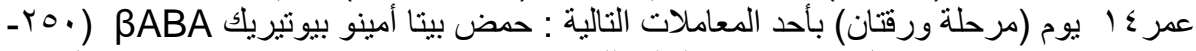

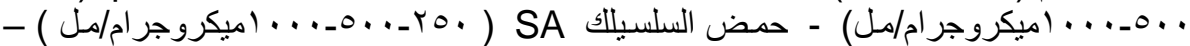

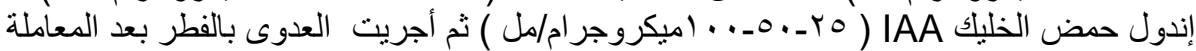
بخمسة أيام ـ وقد كانت البادرات ذات أنات ثلاثة أوراق. وقد أظهرت النتائج ما يلى : البادرات

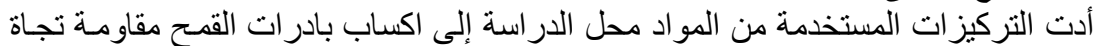

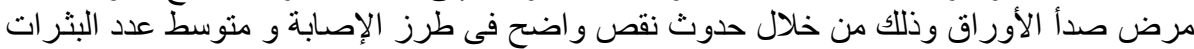

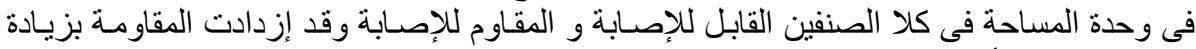

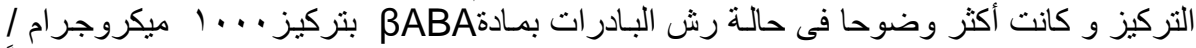

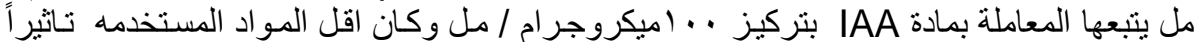

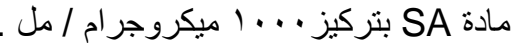

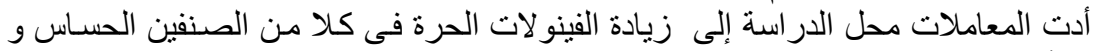

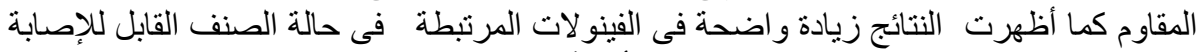

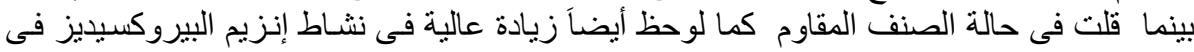

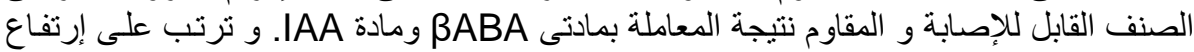

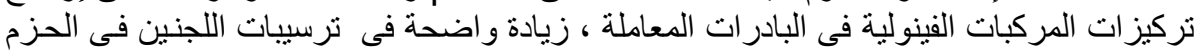

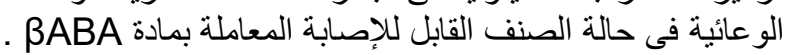

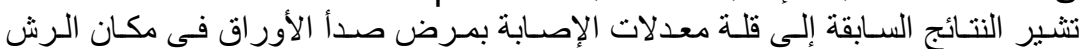

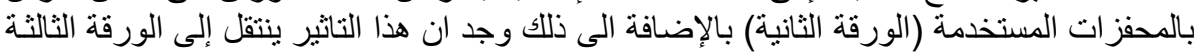

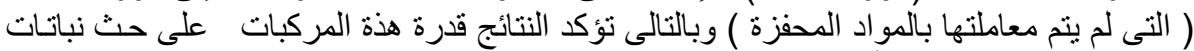

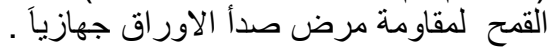

